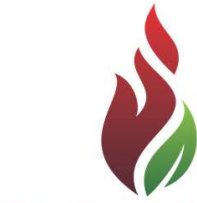

SUSTENERE

Publishing Corporation

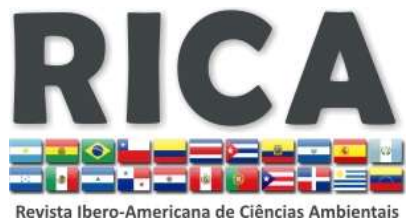

Journals Homepage:

www.sustenere.co/journals

\section{ECOPONTOS: UMA ESTRATÉGIA PARA REDUÇÃO DOS IMPACTOS GERADOS PELOS RESÍDUOS DA CONSTRUÇÃO CIVIL NO MUNICÍPIO DE VITÓRIA DA CONQUISTA (BA)}

\section{RESUMO}

A expansão dos empreendimentos imobiliários e a estabilidade econômica são apenas alguns dos motivos para a geração cada vez mais crescente dos Resíduos Sólidos Urbanos (RCC's), fator norteador desse estudo, uma vez que, os impactos gerados sobrevêm em larga escala no quesito socioambiental. Visto isso, o estudo teve como objetivo geral avaliar a implantação de ecopontos na minimização dos impactos gerados por esse tipo de resíduos em Vitória da Conquista, a terceira maior cidade do interior da Bahia, através do levantamento dos locais com disposições irregulares dos Resíduos da Construção Civil (RCC), bem como pela avaliação dos impactos socioambientais ocasionados pelos mesmos. A metodologia baseou-se num estudo de cunho descritivo e exploratório, por meio de levantamento de dados realizado nas secretarias municipais de Serviços Urbanos e do Meio Ambiente, posteriormente transcritos para melhor análise. Foram encontrados resultados insatisfatórios no que tange à disposição dos RCC's em locais inapropriados, depositados diretamente por geradores ou por empresas contratadas, ocasionando desde a degradação da paisagem natural à proliferação de vetores patogênicos prejudiciais à conjuntura de saneamento e à saúde humana, o que corrobora a urgência na implantação de ecopontos, além de maior ênfase à educação ambiental tanto no nível dos empregadores quanto da população, objetivando redução dos impactos, conflitos, aumentando o bem estar geral da sociedade e do meio ambiente.

PALAVRAS-CHAVES: Eixo Temático; Conflitos Urbanos; Periurbanos.

\section{ECOPOINTS: A STRATEGY FOR REDUCING THE IMPACTS GENERATED BY WASTE CONSTRUCTION IN VITORIA DA CONQUISTA CITY (BA)}

\section{ABSTRACT}

The expansion of real estate development and economic stability are just some of the reasons for the ever-increasing generation of municipal solid waste (RCC's) guiding factor of this study, since the impacts occur on a large scale in the environmental aspect. Seen it, the study aimed to assess the implementation of ecopoints in minimizing the impacts generated by this type of waste in Vitoria da Conquista, the third largest city in the interior of Bahia, through the lifting of places with irregular provisions of the Waste Construction Civil (RCC), as well as for the evaluation of environmental impacts caused by them. The methodology was based on a study of descriptive and exploratory, using data from a survey conducted in the municipal departments of Urban Services and the Environment, later transcribed for further analysis. Unsatisfactory results were found with regard to the disposal of RCC's in inappropriate places, deposited directly by generators or by contractors resulting from the degradation of the natural landscape to the proliferation of pathogenic vectors harmful to sanitation environment and human health, which supports the urgency in the implementation of ecopoints and greater emphasis on environmental education both at the level of employers and the population, aiming to reduce the impacts, conflicts, increasing the general welfare of society and the environment.

KEYWORDS: Thematic Axis; Urban; Peri-Urban Conflicts.
Revista Ibero-Americana de

Ciências Ambientais, Aquidabã, v.6, n.2, Jun, Jul, Ago, Set, Out, Nov 2015.

ISSN 2179-6858

\section{SECTION: Articles}

TOPIC: Saneamento e Tratamento de Resíduos

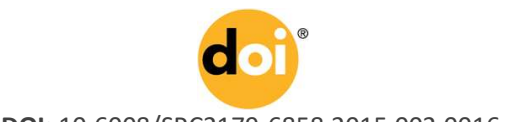

DOI: 10.6008/SPC2179-6858.2015.002.0016

Rubens Jesus Sampaio

Universidade Estadual do Sudoeste da Bahia, Brasil http://lattes.cnpq.br/8116836060125065 rj.sampaio@uol.com.br

Juliana Santos Oliveira

Universidade Federal da Bahia, Brasil http://lattes.cnpq.br/3068173121242996

juli.oliveira.santos@gmail.com

Dirlêi Andrade Bonfim Faculdades Integradas do Nordeste, Brasil http://lattes.cnpq.br/8700071457395895 dirleibonfim@gmail.com

Milton Ferreira da Silva Junior Universidade Estadual de Santa Cruz, Brasi http://lattes.cnpq.br/7535411446526168 notlimf@gmail.com

Received: $21 / 02 / 2015$

Approved: 14/10/2015

Reviewed anonymously in the process of blind peer.

\section{Referencing this:}

SAMPAIO, R. J.; OLIVEIRA, J. S.; BONFIM, D. A. SILVA JUNIOR, M. F.. Ecopontos: uma estratégia para redução dos impactos gerados pelos Resíduos da Construção Civil no município de Vitória da Conquista (BA). Revista Ibero-Americana de Ciências Ambientais, Aquidabã, v.6, n.2, p.227-245, 2015. DOI: http://dx.doi.org/10.6008/SPC21796858.2015 .002 .0016 


\section{INTRODUÇÃO}

Os resíduos sólidos urbanos (RSU) são produzidos em todos os estágios das atividades humanas, sua composição e seu volume variam em função das práticas de consumo, dos métodos de produção, da mudança de hábitos e habitat. Dar a destinação correta aos resíduos sólidos é um dilema que acompanham o homem deste o seu surgimento no planeta. No início, como o homem era nômade, não havia maiores dificuldades a serem sanadas porque o espaço para a deposição era grande e o número de pessoas era pequeno. Ao se fixar formando comunidade surgem os problemas de ordem ambiental, em decorrência dessa mudança de hábitos. Ainda sem maiores conhecimentos técnicos, sem ter uma compreensão holística e sem ter desenvolvido hábitos de higiene, os resíduos gerados eram direcionados, 'naturalmente' para os corpos d'água.

Relatos bíblicos no Antigo Testamento dão conta de que, fora das muralhas da cidade de Jerusalém, um determinado local conhecido como 'Ge Hinom' - Vale do Hinom, existia um imenso depósito de lixo, equivalente aos 'lixões' de hoje. Mas não se tratava de um aterro sanitário. Tudo o que era jogado ali era queimado. Até mesmo restos humanos eram depositados no local. Com o advento da revolução industrial vem o aceleramento da transformação da matéria prima em bens de consumo e, com isso, a geração de resíduos em larga escala. Bastaria, então, diminuir a utilização das matérias primas e aumentar a taxa de recuperação/reciclagem/reutilização dos resíduos para que o problema fosse equacionado. Entretanto, essas medidas, em decorrência de vários aspectos, dentre eles o modelo econômico adotado, tem sido de difícil aplicabilidade ao longo da história humana. De acordo com Williams (2012, p.41), "não há nenhum estado prometido e de algum modo livre de todos os males do capitalismo". Em decorrência disso e com a geração de RSU cada vez maior, a moderna sociedade tem focado suas ações na procura de novas formas de gestão dos resíduos gerados, também tem dirigido seus esforços na procurar de locais para depositá-los. As duas iniciativas descritas tem seu foco numa metodologia ex-post facto e não na perspectiva da não geração.

Como os RSU permanecerão por muitos anos no local onde forem depositados, mesmo que venham sofrer transformações físicas e bioquímicas, trata-se de um problema de alta complexidade, pois a correta gestão de resíduos sólidos é um processo que engloba controle de produção, coleta, armazenamento, transferência e transporte, processamento, tratamento e destino final, de acordo com os melhores princípios de preservação da saúde pública, economia, engenharia, conservação dos recursos naturais, estética e outros princípios ambientais. Por isso, a gestão de resíduos proposta pelas metodologias atuais, tanto em países considerados desenvolvidos, quanto em países considerados em desenvolvimento, bem como os marcos legais que regulam os RSU, pressupõe o funcionamento de uma complexa rede de atores com uma inter-relação entre aspectos políticos, educacionais, administrativos, financeiros, legais, de planejamento e de engenharia. Portanto, são soluções que abarcam conhecimentos científicos e tecnológicos interdisciplinares, envolvendo engenharia, economia, sociologia, geografia, 
planejamento regional, saúde pública, demografia, comunicações, educação, política pública e conservação.

Com o aumento da população mundial hoje estimada em 7,0 bilhões e o grau de urbanização que representa $75 \%$ do total da população vivendo em cidades, torna-se clara a necessidade de uma reavaliação sobre os modelos de produção, consumo e crescimento econômico adotados pela grande maioria dos países, em decorrência da dificuldade do correto gerenciamento e da disposição final de resíduos sólidos urbanos (RSU) gerados. A perspectiva não é animadora se tomarmos como base crescimento do número de grandes cidades. Em 1950 havia apenas uma megalópole com mais de 10 milhões de habitantes no mundo, Nova York. Em 2000 esse número já subira para 19, esperando-se para 201523 megalópoles, entre as quais algumas como Tóquio, Mumbai, Cidade do México, Lagos e São Paulo com mais de 20 milhões de habitantes. Diante do exposto acima este trabalho tem por o objetivo geral avaliar a implantação de ecopontos na minimização dos impactos gerados por esse tipo de resíduos em Vitória da Conquista, a terceira maior cidade o estado da Bahia - Brasil.

\section{REVISÃO TEÓRICA}

\section{Gestão de RSU no Brasil}

Em 2011 o Brasil gerou 61,9 milhões de toneladas de resíduos sólidos urbanos (RSU). Este número é 1,8\% a mais do que no ano de 2010 (Abrelpe, 2011). 55,5 milhões de toneladas de RSU foram coletadas, isto significa $90 \%$ do total gerado. $10 \%$ de tudo o que foi gerado foram depositados em terrenos baldios, ruas, córregos, lagos e praças.

Do total de RSU coletado em 2011, 42\% acabaram em locais inadequados, isto é, lixões e aterros controlados. Levando em conta o ponto de vista ambiental, os aterros controlados têm o mesmo impacto negativo que os lixões. Na prática, são lixões melhorados por serem áreas que não recicla, reaproveita e reutiliza o RSU coletado e não fazem o tratamento do chorume. Nos dois casos o meio ambiente não é protegido, como seria caso os RSU fossem adequadamente depositados em um aterro sanitário como determina e supõe a lei 12305 (Brasil, 2010), que institui a Política Nacional de Resíduos Sólidos (PNRS). Tomando como base os dados do Panorama Brasil 2011 nota-se que em 2011 a situação piorou (Abrelpe, 2011). Em 2010 o volume de destinação inadequada foi de 22,9 milhões de toneladas contra 23,2 milhões de toneladas em 2011. Essa deposição inadequada provoca vários danos ao meio ambiente. Em alguns casos os impactos são irreversíveis.

No ano de 2010 em comparação com 2009 os dados do IBGE (2010) sobre o tema já não davam uma sinalização animadora. A geração de RSU novamente registrou um crescimento expressivo de 2009 para 2010, conforme indica a figura 1. A geração de RSU superou a taxa de crescimento populacional urbano que foi de cerca de $1 \%$ no período. Em $201061 \%$ dos 
municípios brasileiros ainda faziam uso de unidades de destinação inadequada de resíduos, encaminhando-os para lixões e aterros controlados. O Panorama Brasil 2011 indica ainda que dos 5.565 municípios brasileiros, $58,6 \%$ do total, afirmam ter iniciativas de coleta seletiva, o que significa um aumento de $1 \%$ em comparação ao ano anterior. Entretanto, apenas $27,7 \%$ das cidades dispõem de aterros sanitários, segundo dados do Ministério das Cidades (Brasil, 2011).

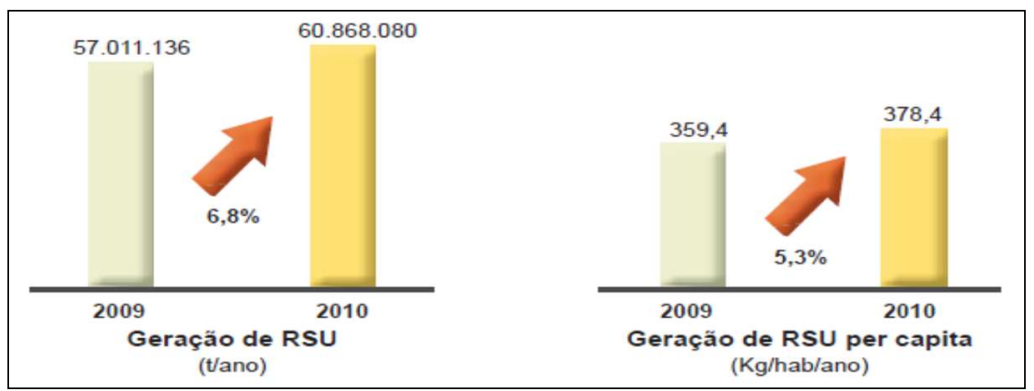

Figura 1: Geração de RSU no Brasil

Fonte: IBGE (2010) e Abrelpe (2010)

De todo o RSU coletado, a região Sudeste responde por $53 \%$ e a região Nordeste por $22 \%$. Nessas duas regiões estão concentrados $75 \%$ de todo o RSU do território nacional. O Brasil ainda tem 4 mil lixões. Deste total, 1,7 mil estão na Região Nordeste. Em relação à coleta de lixo hospitalar, os municípios coletaram e destinaram 237,6 toneladas de resíduos sólidos de saúde (RSS) das quais $40 \%$ têm destino inadequado, indo para lixões, sendo depositados sobre o solo sem tratamento prévio, não só contaminando o meio ambiente, mas trazendo um risco muito grave para as pessoas que catam resíduos nesses lixões.

Segundo Hawken et al. (2004) somente a indústria da construção civil consome um terço da energia total, dois terços da elétrica e um quarto de toda a madeira colhida; no mundo, empregam-se anualmente três bilhões de toneladas de matéria-prima na construção. Estima-se que a construção civil consome algo entre 20 e $50 \%$ do total de recursos naturais consumidos pela sociedade (SJOSTROM, 1996). O consumo de agregados, por exemplo, é imenso. Em decorrência da alta utilização de recursos naturais, algumas reservas de matérias-primas, como por exemplo o cobre, tem vida útil estimada de pouco mais de 60 anos (Industry Enviroment, 1996). Em uma cidade como São Paulo o esgotamento das reservas próximas a capital faz com que a areia natural já seja transportada de distâncias superiores a $100 \mathrm{~km}$, implicando em enormes consumos de energia e são grandes geradores de poluição, dada sua dispersão espacial, transporte a grandes distâncias. Cerca de $80 \%$ da energia utilizada na produção do edifício é consumida na produção e transporte de materiais (Industry Enviroment, 1996).

Neste ponto, vale ressaltar que ainda não conhecemos e não temos como avaliar os custos da degradação. Se fizermos cálculos frios, veríamos que algumas medidas de proteção ambiental e de concertos ecológicos são mais dispendiosas do que os próprios danos sofridos pelo meio ambiente. É impossível monetizar as transformações da natureza causadas pelo homem. A natureza não se deixa avaliar em grandezas monetárias, por isso não dispomos de um critério que nos permita medir e comparar com segurança os custos do impedimento e do 
conserto de danos ambientais nem dos próprios danos ambientais. Mais difíceis ainda são os limites da avaliação monetária da preservação da natureza e dos danos por ela sofridos quando consideramos a evolução. Simplesmente não sabemos nada sobre os efeitos secundários, terciários etc., sobre os danos ambientais, por exemplo, do efeito estufa. Por causa dessa insegurança insuperável, a Conferência da ONU sobre Meio Ambiente e Desenvolvimento realizada em 1992 no Rio de Janeiro, declarou o princípio da prevenção como fio de prumo de toda e qualquer ação política (ALTVATER, 2010, p.224).

\section{Política Nacional de Resíduos Sólidos}

A Política Nacional de Resíduos Sólidos (PNRS) determina que a prioridade na gestão dos resíduos não é voluntária e sim obrigatória, prevendo a não geração, a redução, a reutilização, a reciclagem e o tratamento. Prevê ainda a adoção da logística reversa, por meio de ações para coletar os resíduos sólidos e devolvê-los ao setor empresarial. Inicialmente, a logística reversa engloba o recolhimento de resíduos e embalagens de agrotóxicos; pilhas e baterias; pneus; óleos lubrificantes; lâmpadas fluorescentes, de vapor de sódio e mercúrio e de luz mista; e produtos eletroeletrônicos e seus componentes.

Vale ressaltar que em agosto de 2014 acabou o prazo para o cumprimento da Lei 12.305/2010 (PNRS) onde a meta estabelecida é acabar com os lixões em todo o país, além de investir em cooperativas de catadores e em parcerias para aumentar a coleta seletiva e da destinação adequada do lixo não reciclável. Dados divulgados pelo Instituto de Pesquisa Econômica Aplicada (IPEA), Folha de São Paulo, agosto de 2014, dos 5.565 municípios brasileiros, 2.507 ainda destinam o lixo coletado para lixões, ou seja, os RSU são depositados em áreas sem nenhum controle ambiental.

A PNRS determina que os aterros devem receber apenas rejeitos, ou seja, aquilo que não é possível reciclar ou reutilizar e serão estruturas que devem ter o preparo do solo para evitar a contaminação de lençol freático e captarão o chorume que resulta da degradação do lixo. Além destas determinações, como mesmo com a disposição final adequada os RSU produzem emissões de gases causadores do efeito estufa, os aterros deverão gerar energia com a captação dos gases gerados. Para estimar a composição e o quantitativo do biogás a ser produzido no aterro, pode ser utilizado o modelo matemático do Intergovernmental Panel on Climate Change (IPCC) (Model, 2013).

Com a implementação das medidas determinadas pela PNRS, um dos objetivos é alcançar um índice de reciclagem de resíduos da ordem de 20\% em 2015. Os dados indicativos de 2011 não sinalizam de que estamos indo na direção requerida pelo dispositivo legal, a Lei 12305/2010 (Brasil, 2010). 


\section{Conceito de Ecoponto Versus o de Lixões e o de Aterro Sanitário}

Todo o arcabouço legal: Lei 12305/2010 e Resolução CONAMA 307/2002, bem como, as metodologias propostas para a gestão dos RSU são dispositivos eminentemente técnicos que, em um primeiro momento, estão orientados com o objetivo de estabelecer ${ }^{2}$ técnicas disciplinares e, num segundo momento, voltados para questões econômicas e procedimentos técnicos que tratam o problema dos impactos ambientais dos RSU sem levar em consideração, a priori, as questões humanas. Entende-se que os conceitos de políticas públicas ambientais, propostos pelo aparato legal e metodológico são mecanismos sociais do Estado que tem como objetivo maior a 'Governamentalidade'.

Ecopontos tem sido implantados para a captação dos mais variados tipos de resíduos. Desde RSU como são os casos de São Paulo, Guarulhos e várias Províncias de Portugal, até casos mais específicos como vidros, óleos utilizados em frituras, óleos automotivos e resíduos da construção civil (RCC). Neste artigo considera-se ecoponto como uma unidade exclusiva para a recepção dos RSU gerados, com o propósito de redução dos impactos ambientais da deposição irregular e parte de uma política pública para a gestão integral desses resíduos que atenda aos marcos legais. A figura 2 apresenta um ecoponto em funcionamento na cidade de Guarulhos (SP).

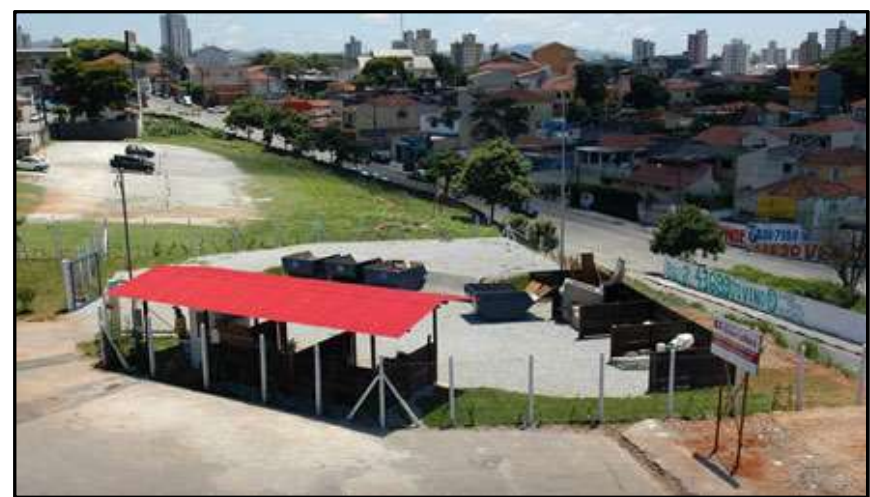

Figura 2: Ecoponto padrão para a recepção de RCC. Fonte: Prefeitura Municipal de Guarulhos (2010)

Pinto (2005) diferencia bota-foras pela dimensão da área pública ou privada utilizada para atividades de aterro realizadas sem nenhum controle técnico. Essas áreas quase sempre são oferecidas para aterramento porque há interesse em corrigir sua topografia, e, comumente, se esgotam com rapidez. Por isso, é comum encontrar diversos bota-foras operando simultaneamente em um mesmo município, muitos deles clandestinos.

Os lixões constituem a forma mais antiga, precária, perniciosa, e abominável de disposição de resíduos sólidos, porque são instituídos sem qualquer estudo, preocupação ou precaução. Os lixões são capazes de atingir o lençol freático, e os cursos d'água. Além disso, são causadores de poluição do solo e da água sob a superfície, e de destruição da vegetação. Causam, ainda, mau cheiro e apodrecimento, atraindo, com isso, moscas, baratas e ratos, entre outros animais 
peçonhentos; e são responsáveis pela desvalorização de imóveis que os circundam. E pior: os lixões são causadores de doenças como a cólera, infecções e verminoses.

A Política Nacional de Resíduos Sólidos (PNRS) determina que os aterros devem receber apenas rejeitos, ou seja, aquilo que não é possível reciclar ou reutilizar e serão estruturas que devem ter o preparo do solo para evitar a contaminação de lençol freático e captarão o chorume que resulta da degradação do lixo. Além destas determinações, como mesmo com a disposição final adequada os RSU produzem emissões de gases causadores do efeito estufa, os aterros deverão gerar energia com a captação dos gases gerados.

Os aterros sanitários, que não podem, de forma alguma, ser confundidos com lixões, são instituídos após um estudo prévio de impacto ambiental, e com imposição de posturas técnicas a serem seguidas, na forma da Lei federal $n^{0} 12.305 / 10$, pois trata-se de uma obra de engenharia complexa, com grandes áreas impermeabilizadas, sistemas de medição de gases e de escoamento de chorume. Os aterros dependem de uma área extensa para serem instalados, na qual o solo é preparado com mantas especiais para não atingir o lençol freático. Ao contrário dos lixões, nos aterros não se verifica a contaminação por chorume - líquido mal cheiroso proveniente da decomposição de matéria orgânica -, que é canalizado para ser tratado. Além disso, os aterros possuem válvula de escape de gases, para que não causem contaminação no local onde estiverem localizados.

Com todo efeito, os aterros constituem locais onde os resíduos são depositados e confinados, sem causar maiores danos ao meio ambiente, porque nesses locais os resíduos são comprimidos por máquinas, que diminuem seu volume, e após, com um trator, os resíduos são empurrados, espalhados e amassados sobre o solo, o que se chama de compactação; por fim, os resíduos são cobertos por uma camada de areia ou argila, que minimiza os odores, e também a proliferação de insetos. O artigo 15, da Lei federal $n^{\circ} 12.305 / 10$, inc. V, que:

\begin{abstract}
A União elaborará, sob a coordenação do Ministério do Meio Ambiente, o Plano Nacional de Resíduos Sólidos, com vigência por prazo indeterminado e horizonte de 20 (vinte anos, a ser atualizado a cada 4 (quatro) anos, tendo como conteúdo mínimo: [...] $\vee$ - metas para a eliminação e recuperação de lixões, associadas à inclusão social e à emancipação econômica de catadores de materiais reutilizáveis e recicláveis.
\end{abstract}

Disposição que evidencia a preocupação da lei com a erradicação dos lixões, e o incentivo à reciclagem e a reutilização de resíduos. Tal previsão existe também para os Planos Estaduais de Resíduos Sólidos (art. 17, V, da Lei 12.305/10). E, ainda, o art. 47, inc. II, da Lei no 12.305/10, proíbe o lançamento de resíduos in natura a céu aberto, sendo excetuados os resíduos de mineração. Já aterro controlado, é um lixão adaptado, mas sem controles ambientais necessários para evitar a contaminação do solo com as sustâncias tóxicas do lixo e de sua deterioração.

\title{
METODOLOGIA
}

Segundo Lima e Lima (2009), a implantação de uma rede de Ecopontos e áreas para 
manejo de grandes volumes (áreas de triagem e transbordo áreas de reciclagem, áreas de aterro) criam as condições de infraestrutura para uma gestão diferenciada como objetivo de dar cumprimento aos princípios do desenvolvimento sustentável e do descarte dos rejeitos em locais ambientalmente corretos. A definição física da rede de pontos de entrega para pequenos volumes foi feita a partir das informações colhidas durante o diagnóstico do município, através do mapeamento dos locais de deposição irregular dos resíduos. Neste caso, o local identificado como bota-fora pode ser adequado e ser transformado em ecoponto, aproveitando assim a disposição pré-existente dos geradores em colocar os resíduos naquele espaço.

Segundo Pinto (2005) conhecendo a localização das deposições irregulares e o perfil dos agentes geradores e coletores dos pequenos volumes, é possível definir os limites das bacias de captação e a localização dos pontos de entrega voluntária, respeitando-se, tanto quanto seja tecnicamente possível e financeiramente viável, os atuais fluxos de coleta e lançamento desses resíduos. As "bacias de captação de resíduos" são áreas de características relativamente homogêneas, com dimensão tal que permita o deslocamento dos pequenos coletores de seu perímetro até o respectivo ponto de entrega voluntária, inibindo, assim, o despejo irregular dos resíduos, pela facilidade conferida à sua entrega num local para isso designado. Sempre que possível esse ponto deve estar situado nas proximidades do centro geométrico da "bacia de captação" a que irá servir, e, de preferência, onde já ocorra uma deposição irregular. Disciplinamse, com isso, atividades que já ocorrem espontaneamente.

De acordo Pinto (2005), para definir os limites da bacia, que ficará explicitado no mapa apresentado, devem ser levados em conta os seguintes fatores: A capacidade de deslocamento dos pequenos coletores equipados com carrinhos, carroças e outros pequenos veículos em cada viagem, ou seja, algo entre $1,5 \mathrm{~km}$ e $2,5 \mathrm{~km}$; A altimetria da região, para que os coletores não sejam obrigados a subir ladeiras íngremes com os veículos carregados, para realizar o descarte dos resíduos; As barreiras naturais que impedem ou dificultam o acesso ao ponto de entrega.

De acordo com John (2001), estima-se uma geração de resíduo muito variável, onde os valores encontrados pelo autor em bibliografias internacionais variam de 163 a mais de 3000 $\mathrm{kg} / \mathrm{hab}$.ano, somente levando em conta os RCC e os valores típicos são estabelecidos na faixa de 400 e 500 Kg/hab.ano, que são valores iguais ou superiores aos RSU. De acordo com Pinto (1999c), estima-se que somente a geração per capta de RCC no Brasil variam de 230-760 $\mathrm{kg} / \mathrm{hab}$.ano. Estas informações servem como base para o auxílio no dimensionamento dos Ecopontos, bem como para posteriores estudos sobre viabilidade econômica de reciclagem de RSU.

A construção e a instalação de Ecopontos têm como objetivo reduzir os danos ambientais, os prejuízos estéticos, a proliferação de vetores e a redução de custos para a gestão municipal, decorrentes da acumulação de RSU em áreas públicas e terrenos, além de incentivar a separação de materiais recicláveis, pelos pequenos geradores, cumprindo assim o dever atribuído pelos marcos legais que normatizam a ação pública em relação aos RSU, principalmente Lei 12.305 
Política Nacional de Resíduos Sólidos (PNRS) I e a Resolução CONAMA 307/02. O objetivo é proporcionar à população uma alternativa ambientalmente adequada para a disposição dos resíduos. Nestes locais os RSU são depositados em caixas metálicas padronizadas e estacionárias de $6 \mathrm{~m}^{3}$, as quais são removidas por veículos poliguindastes e transportados para a Usina de Reciclagem ou à correta destinação final.

Além das caixas metálicas estacionárias de $6 \mathrm{~m}^{3}$, o Ecoponto deve ter ainda uma pequena construção com infraestrutura básica, identificando o Ecoponto, que serve como acomodação do gari encarregado do local de recepção e orientação de todos que procuram o Ecoponto para depositar seus resíduos sem prejuízo do meio ambiente. O limite estabelecido para o volume máximo das cargas individuais de resíduos que possam ser recebidos no Ecoponto, que atenderá à rede de pequenos volumes, é de $2 \mathrm{~m}^{3}$. Nessas unidades, no primeiro momento, deve ser proibido o descarte de resíduos orgânicos domiciliares, de resíduos industriais e de resíduos dos serviços de saúde. De acordo com Pinto (2005), devem constar no projeto dos pontos de entrega os seguintes aspectos: uma delimitação da área, para reforçar a imagem de qualidade ambiental; aproveitar desnível existente, ou criar um platô, para que a descarga dos RSU pesados seja feita diretamente no interior de caçambas metálicas estacionárias; garantir os espaços para as manobras dos veículos, além dos veículos de carga responsáveis pela remoção posterior dos resíduos acumulados; identificar, por meio de placa de sinalização, a finalidade da instalação pública, como local correto para o descarte dos RSU.

No que diz respeito ao layout, é necessário que se instale no Ecoponto uma pequena guarita, com sanitário e telefone, para facilitar a presença contínua de um funcionário. O Ecoponto deve ocupar áreas públicas ou áreas privadas cedidas em parceria, ou, ainda, áreas alugadas ou arrendadas para tal finalidade, de preferência, utilizando "retalhos de formato irregular" resultantes do arruamento urbano, com área entre $200 \mathrm{~m}^{2}$ e $600 \mathrm{~m}^{2}$. As áreas públicas poderão ser bens dominiais, áreas institucionais subutilizadas ou, ainda trechos de áreas verdes que se encontrem deteriorados, sem capacidade de exercer seu papel.

\section{RESULTADOS}

\section{Diagnóstico dos RSU em Vitória da Conquista: Mapeamentos}

Foi realizada uma verificação com o objetivo de identificar todos os locais com deposição inadequada dos RSU, a fim de colher informações para a sugestão dos pontos onde serão indicados a implantação de Ecopontos bem como da Usina de Reciclagem.

Também foi realizado um levantamento em toda a área urbana da cidade onde foram identificados todos os locais identificados como bota-fora. Neste trabalho foi realizada a observação direta intensiva não participante, juntamente com registro fotográfico e notas pessoais. O registro fotográfico gerou um banco de imagens possibilitando a análise visual 
comparativa no estudo da dinâmica das deposições nessas áreas e, também, para detecção dos impactos locais não observados durante a coleta desses dados. As anotações foram registradas e formatadas em um mapa digitalizado.

\section{Mapeamento dos Bota-Foras}

Brasil (2005) diferencia bota-foras pela dimensão da área pública ou privada utilizada para atividades de aterro realizadas sem nenhum controle técnico. Essas áreas quase sempre são oferecidas para aterramento porque há interesse em corrigir sua topografia, e, comumente, se esgotam com rapidez. Por isso, é comum encontrar diversos bota-foras operando simultaneamente em um mesmo município, muitos deles clandestinos. Brasil (2005) identificou que em 1996 Vitória da Conquista tinha 92 locais com deposição irregular de RCC e 2 bota-foras clandestinos de RCC. A Tabela 1 mostra situação de Vitória da Conquista de acordo com o resultado da presente pesquisa.

Tabela 1: Bota-foras mapeados em Vitória da Conquista.

\begin{tabular}{l|l|l|l|l}
\hline Local & Agosto & Setembro & Outubro & Novembro \\
\hline Estrada de Barra do Choça & 1 & 2 & 2 & 2 \\
\hline Aeroporto & 1 & 1 & 1 & 1 \\
\hline Rodovia BA 263 & 1 & 1 & 1 & 1 \\
\hline Anel Viário Leste & 1 & 1 & 1 & 1 \\
\hline Bairro Universitário & 2 & 2 & 2 & 2 \\
\hline Serra do Periperi & 1 & 1 & 1 & 1 \\
\hline Vila Serrana & 1 & 1 & 1 & 1 \\
\hline Anel Viário Sul & 1 & 1 & 1 & 1 \\
\hline Anel Viário Norte & 1 & 1 & 1 & 1 \\
\hline Alto da Serra (SESI) & 1 & 1 & 1 & 1 \\
\hline Av. Luiz Eduardo - Rio Verruga & 1 & 1 & 1 & 1 \\
\hline Recreio - Rio Verruga & 1 & 1 & 1 & 1 \\
\hline Anel Viário Oeste & 1 & 1 & 3 & 3 \\
\hline Estrada de Campinhos & - & - & - & 2 \\
\hline TOTAL & $\mathbf{1 4}$ & $\mathbf{1 5}$ & $\mathbf{1 7}$ & $\mathbf{1 9}$ \\
\hline
\end{tabular}

Fonte: Sampaio (2011).

O mapeamento das áreas realizado por esta pesquisa, além de identificar e apontar os pontos de deposição irregular de RSU apresenta dados atualizados dos bota-foras existentes em toda a cidade. Durante o mapeamento em todo o perímetro urbano da cidade de Vitória da Conquista no mês de agosto foram identificados quatorze locais de bota-foras.

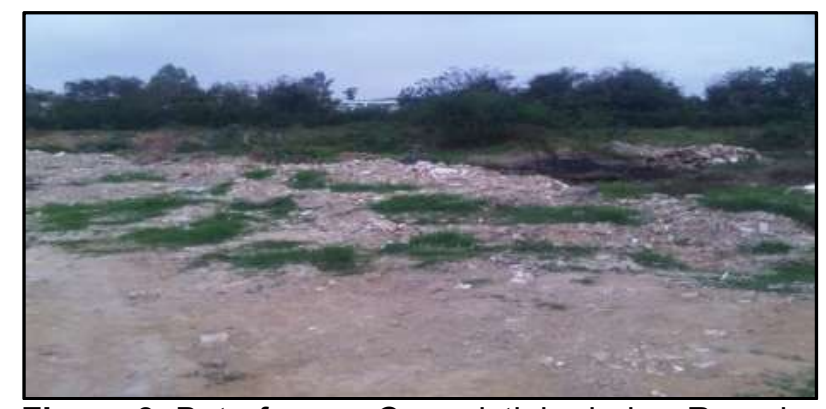

Figura 3: Bota-fora na Conquistinha bairro Recreio.

Fonte: Sampaio (2011) 
No mês de agosto de 2012, quando foi realizado o primeiro mapeamento, já estavam em operação treze bota-foras para o descarte de RSU. Chama a atenção, conforme indicam os marcadores na cor azul, que seis dos treze bota-foras estavam localizados nos bairros Recreio e Candeias. Os outros sete conforme os marcadores em vermelho estão distribuídos por vários bairros da cidade, exclusivamente na periferia. Conforme indicado pela tabela 1 e pela figura 4 , durante o mapeamento realizado no mês de setembro foi verificada a existência de um novo botafora nas proximidades de um conjunto residencial em construção, fazendo com que aumentassem de treze para quatorze os bota-foras existentes.

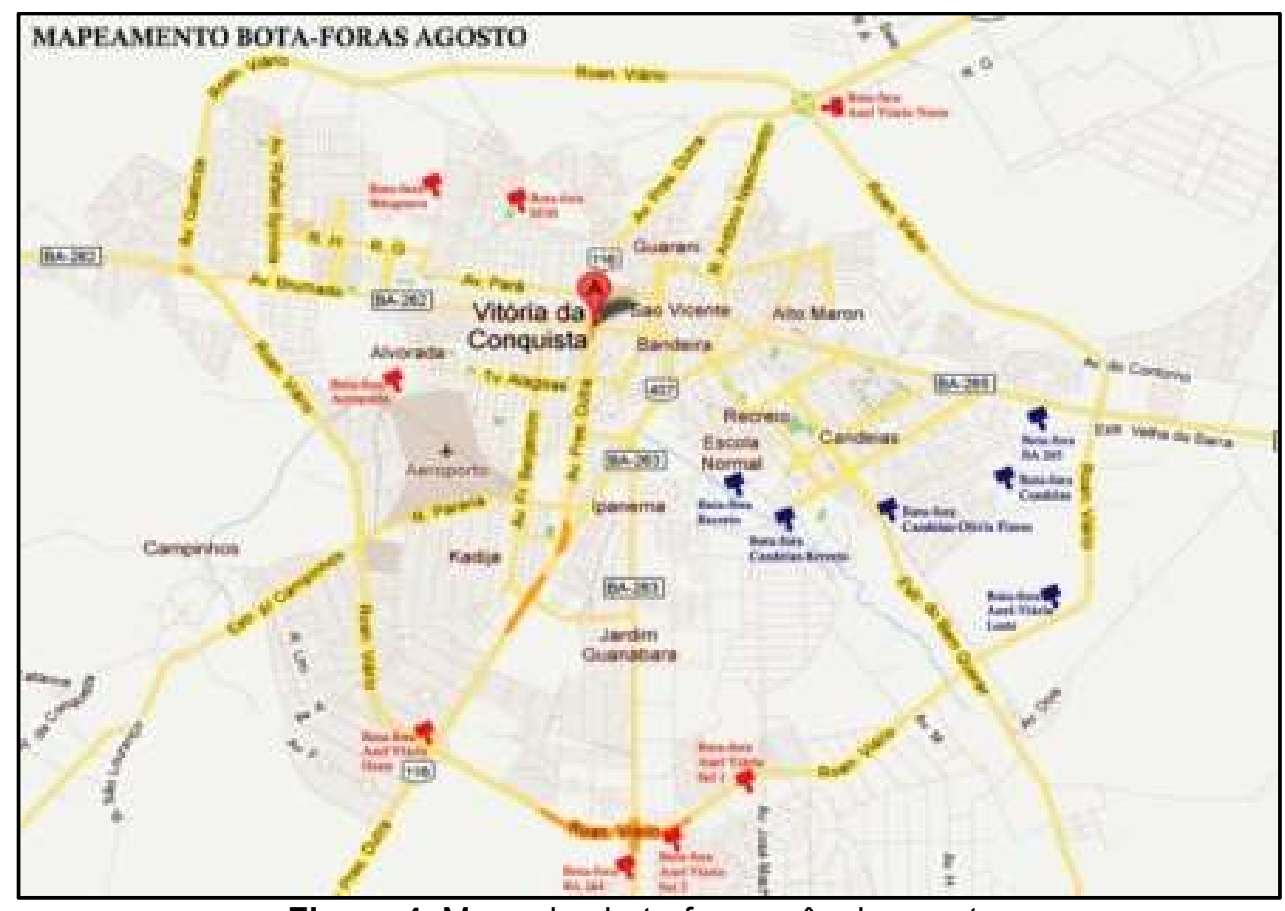

Figura 4: Mapa dos bota-foras mês de agosto.

Fonte: Sampaio (2011).

Conforme indica a figura 6, o marcador na cor verde, este novo bota-fora fica na divisa do bairro Candeias às margens da BA 265, estrada que liga Vitória da Conquista à cidade de Barra do Choça. Nas proximidades deste novo bota-fora já há outro em atividade.

Como uma vala impede o acesso do referido conjunto à BA 265 e há no RSU depositado: gesso, alvenarias cortadas e argamassa, as evidências indicam que os resíduos depositados foram gerados pela construtora responsável pela obra e tem como objetivo aterrar a vala existente. Este tipo de deposição impede que estes RSU sejam posteriormente reintroduzidos na cadeia produtiva, conforme estabelecem tanto a resolução CONAMA 307/2002, quanto a Lei Federal 12305/2011 (Brasil, 2002, 2011). Os referidos marcos legais também determinam exigências de controle ambiental e da gestão sustentável de recursos ambientais naturais, cabe aos municípios e ao Distrito Federal a fiscalização e o controle para que os resíduos sejam depositados da maneira adequada. 


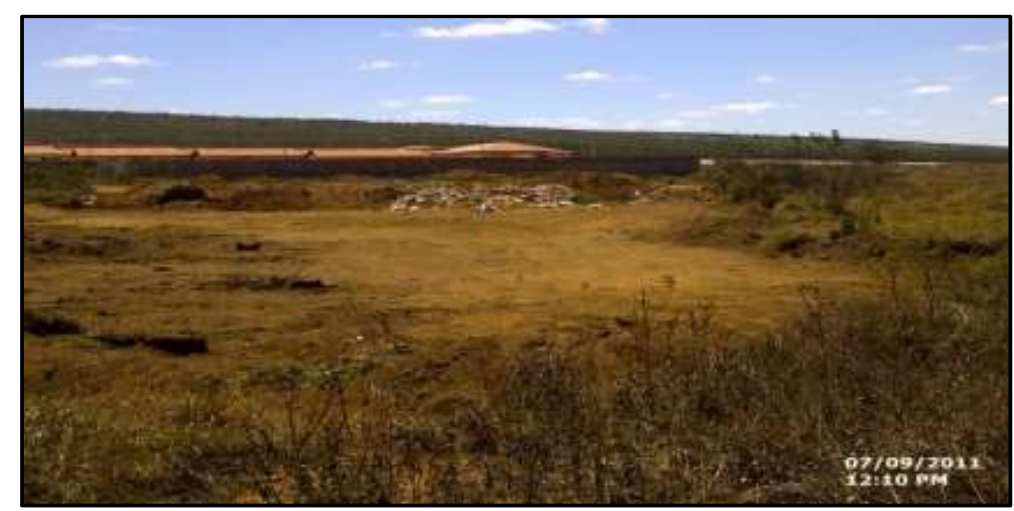

Figura 5: Novo bota-fora na BA 265.

Fonte: Sampaio (2011)

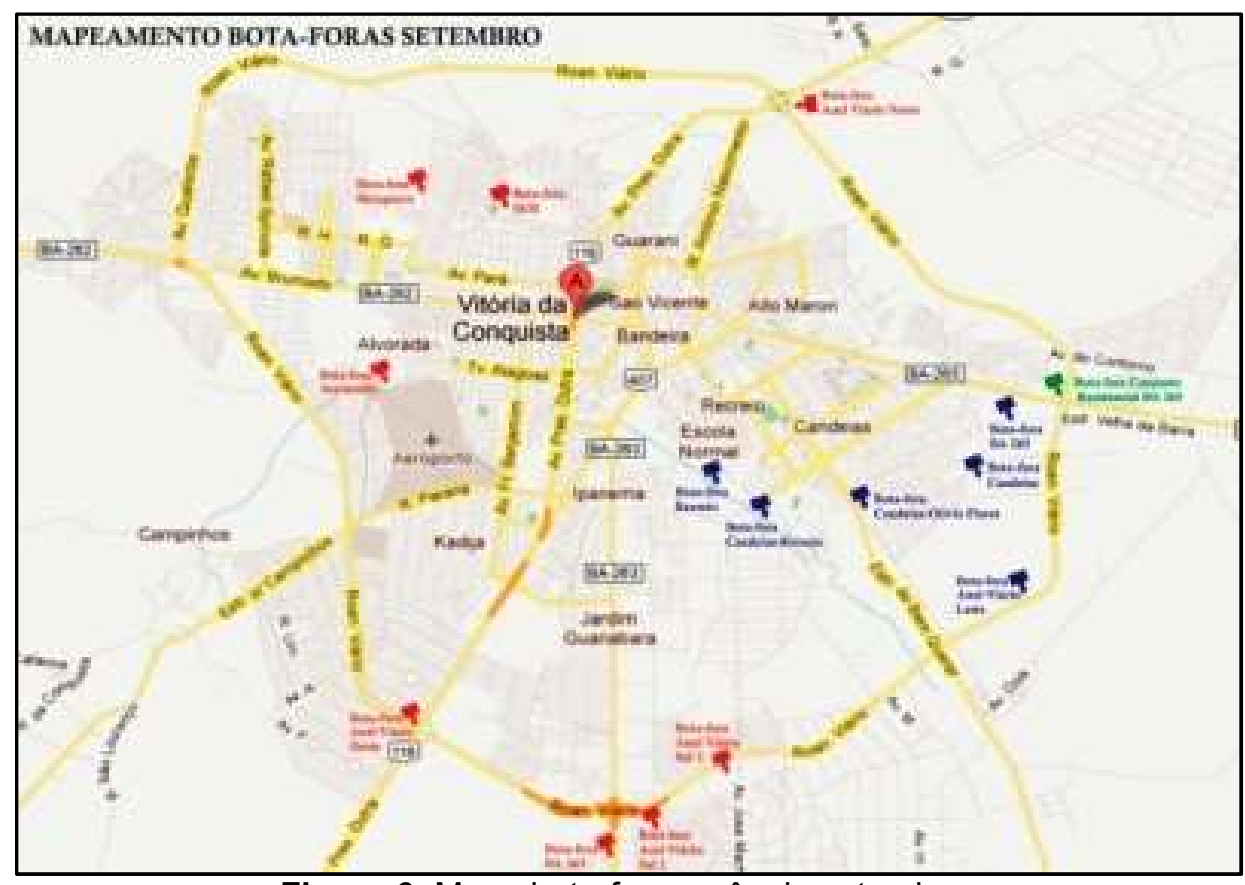

Figura 6: Mapa bota-foras mês de setembro.

Fonte: Sampaio (2011).

A lei municipal 1.410/2007, denominada Código Municipal do Meio Ambiente em seu artigo 247, considera que a deposição irregular de RSU é uma infração gravíssima, pois tem três ou mais circunstâncias agravantes e por isso é passível de multa pecuniária no valor que vai entre $\mathrm{R} \$$ $10.001,00$ a $\mathrm{R} \$ 50.000,00$. O artigo 255 da mesma lei prevê que em caso de infração continuada, a multa pecuniária pode ser diária no valor entre $\mathrm{R} \$ 50,00$ e $\mathrm{R} \$ 50.000,00$ (PMVC, 2007). No mapeamento realizado no mês de outubro, os quatorze bota-foras identificados no mês de setembro estavam em operação conforme indicam as Figuras 7, 8 e 9 do bota-fora existente na BA 265, estrada de Barra do Choça. Quando do mapeamento realizado em agosto, ainda havia muito espaço de deposição de RCC, figura 7. No mês de setembro os montes de RSU já estavam acentuados com a deposição de resíduos por caminhões-caçamba, figura 8. em outubro, conforme demonstra a figura 9, o espaço está quase que totalmente tomado. Os RSU depositados ocupam uma área maior já se aproximando da rodovia. 


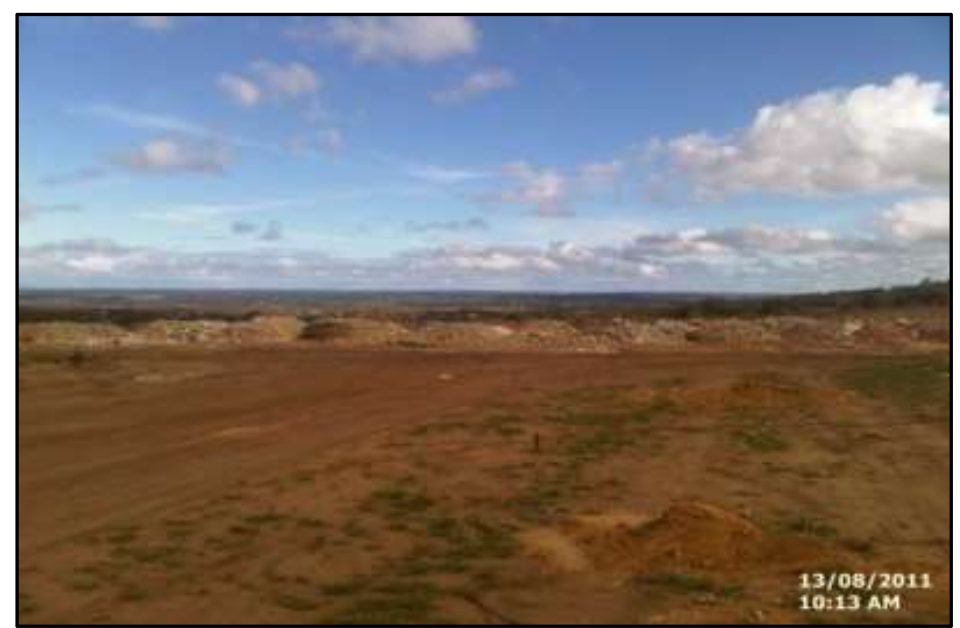

Figura 7: Bota-fora BA 265 mês de agosto.

Fonte: Sampaio (2011).

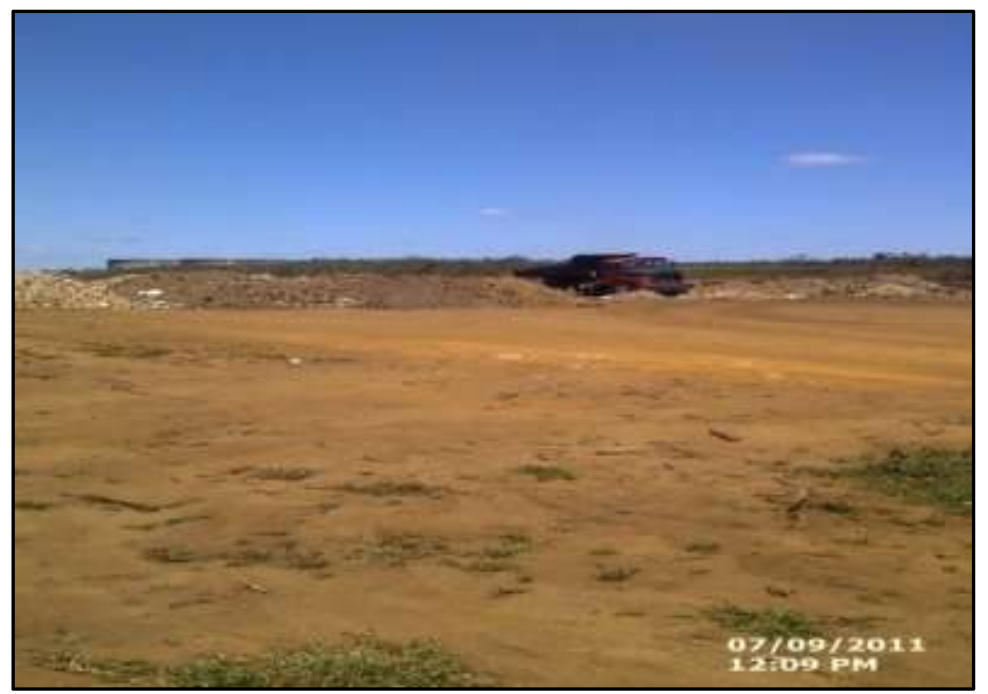

Figura 8: Bota-fora BA 265 mês de setembro.

Fonte: Sampaio (2011)

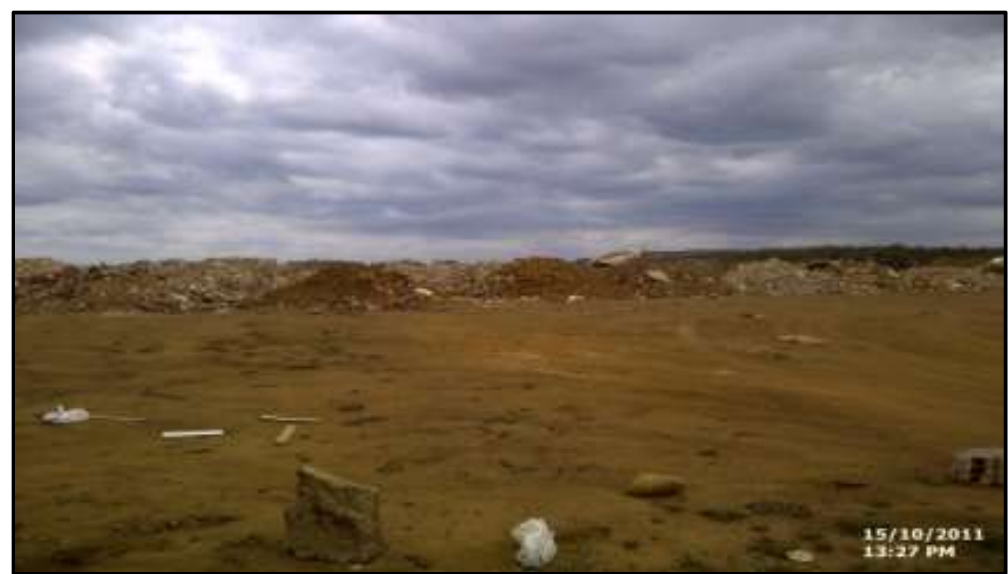

Figura 9: Bota-fora BA 265 mês de outubro.

Fonte: Sampaio (2011).

Também foram identificados mais dois locais de bota-fora na parte norte do anel viário, conforme indicam os marcadores na cor azul clara, figura 10. Ambos estão na serra do Peri Peri, num espaço ainda não povoado. 


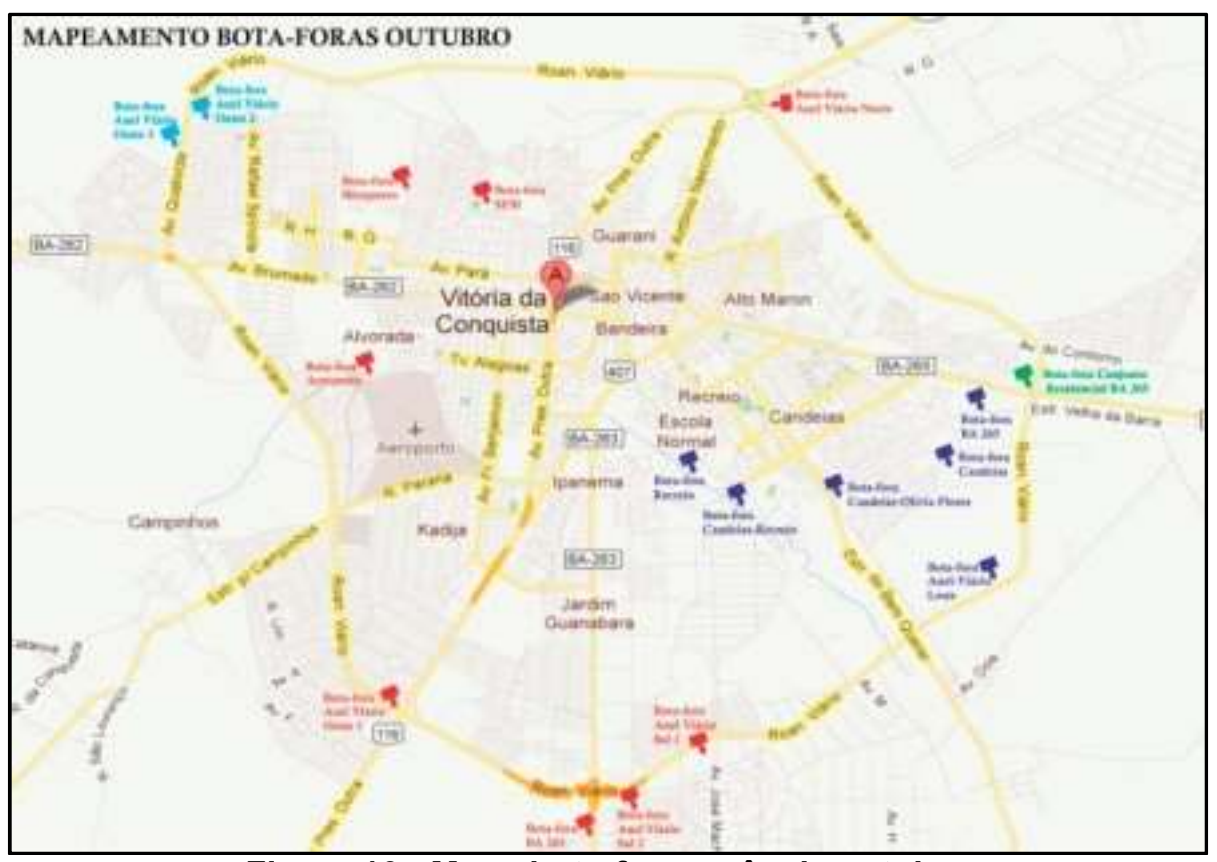

Figura 10 - Mapa bota-foras mês de outubro

Fonte: Sampaio (2011)

Da mesma forma que o novo bota-fora identificado na BA 265 no mês de setembro, figura 5 , os dois bota-foras estão nas proximidades de um conjunto residencial em fase de construção.

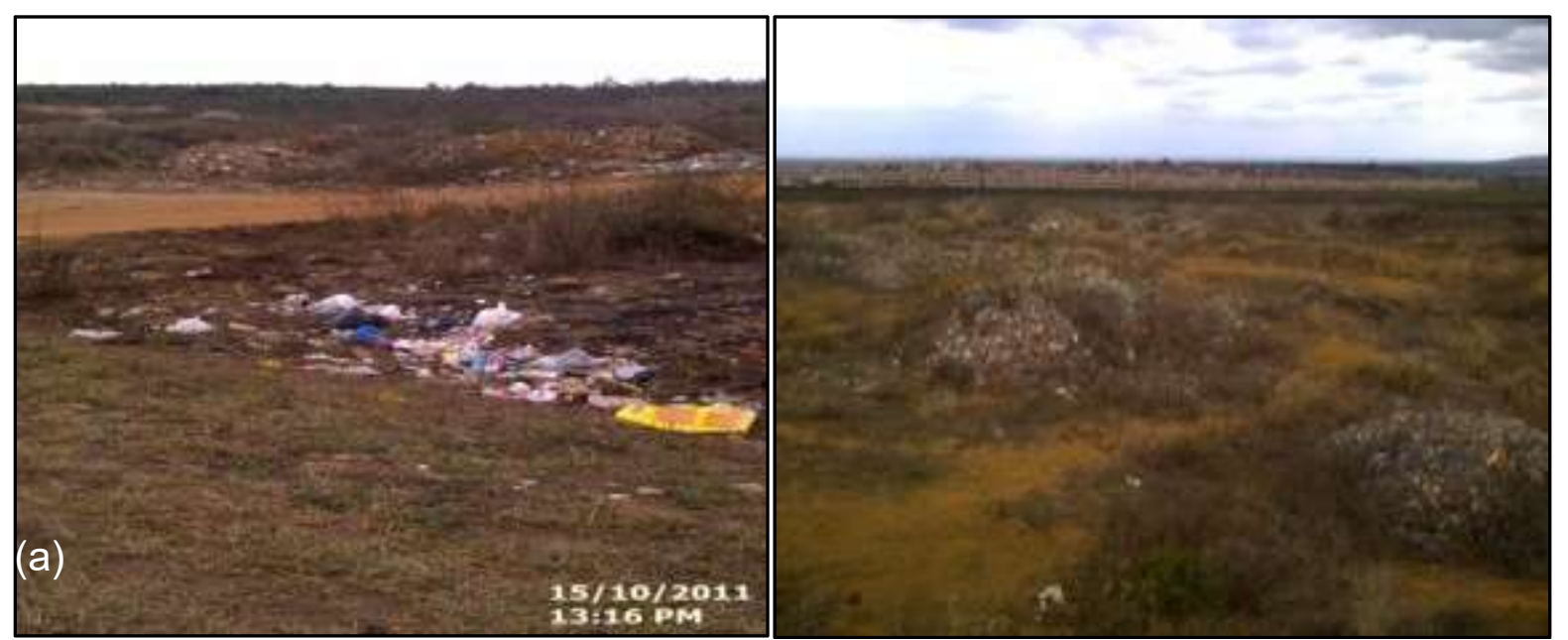

Figura 11: Novos bota-foras no anel viário oeste. (a) lado oposto ao conjunto residencial, (b) próximo ao conjunto residencial

Fonte: Sampaio (2011).

Em novembro, mais dois novos bota-foras foram identificados as margens do anel rodoviário no entroncamento que leva ao Povoado dos Campinhos, conforme indicam a tabela $1 \mathrm{e}$ as figuras 12, 13 e 14. Ambos estão em plena atividade. 


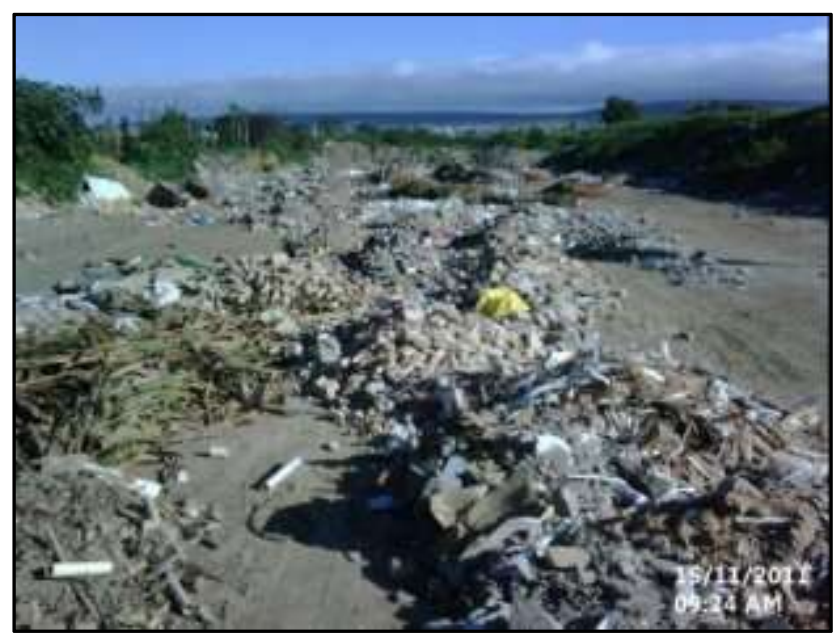

Figura 12: Novo bota-fora estrada Povoado dos Campinhos.

Fonte: Sampaio (2011)

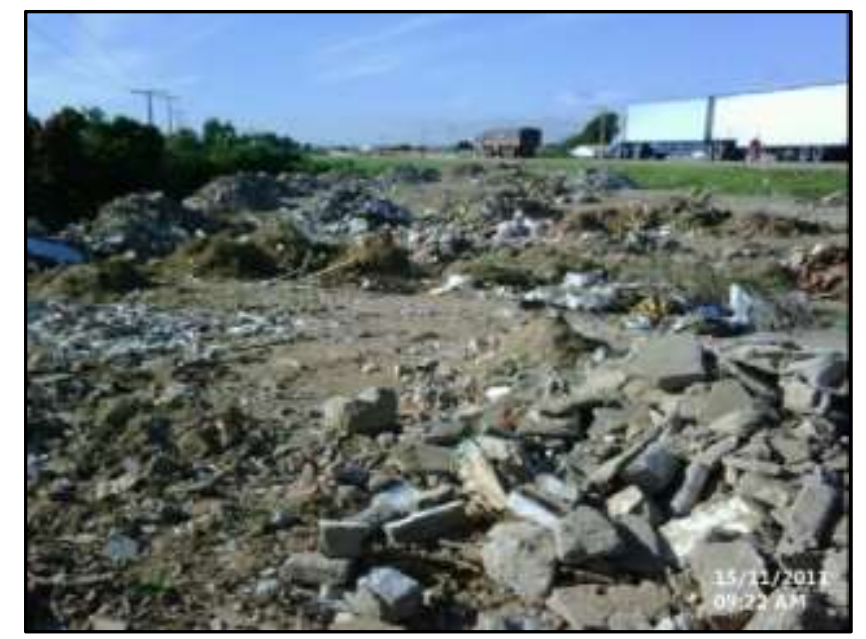

Figura 13: Novo bota-fora anel viário oeste.

Fonte: Sampaio (2011)

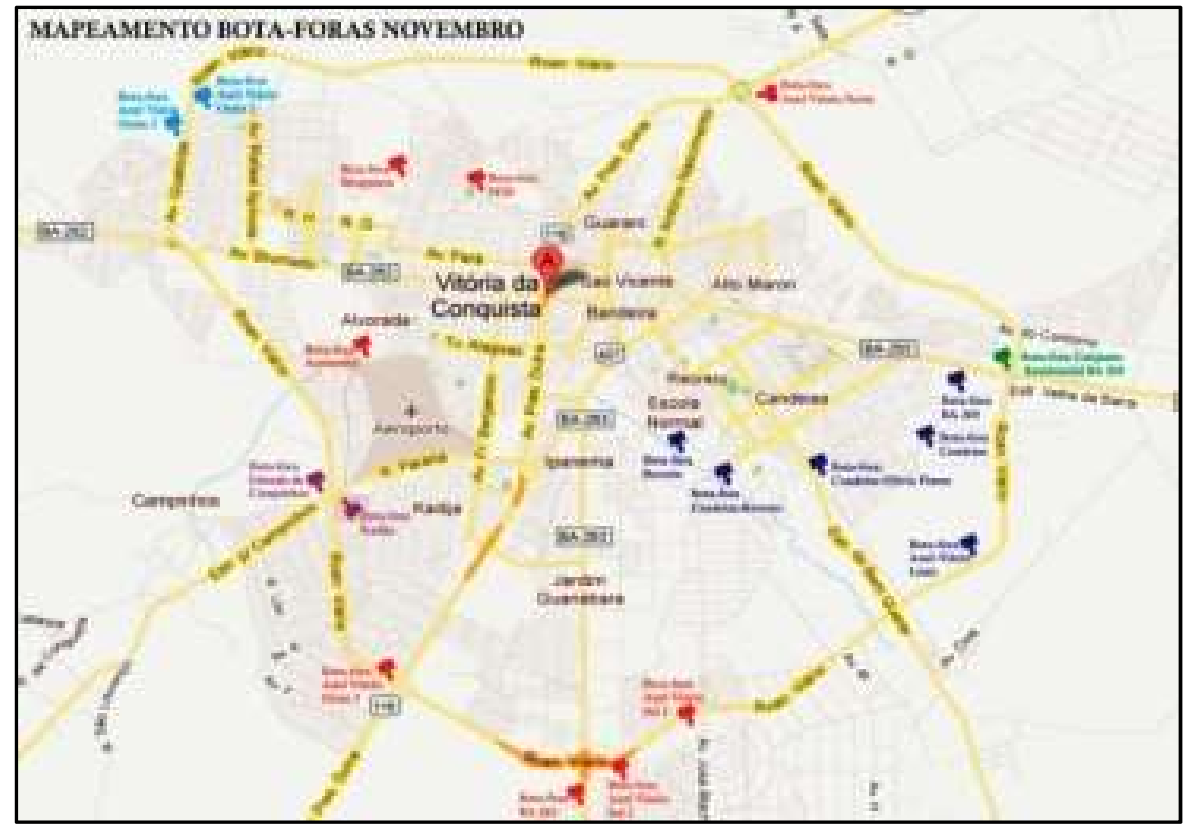

Figura 14: Mapa bota-foras mês de novembro.

Fonte: Sampaio (2011)

Durante os cinco meses de duração desta pesquisa, não foi observada a presença de 
qualquer tipo de fiscalização o sinais de remoção dos RSU para um local ambientalmente adequado. Os resíduos são depositados em qualquer hora do dia sem qualquer preocupação com a possibilidade de multa ou repressão por parte do poder público municipal. Há a indicação de um acordo tácito entre os geradores, os que depositam os RSU e as entidades públicas responsáveis pela fiscalização. Constatou-se que a deposição irregular de entulhos no Município de Vitória da Conquista vem crescendo de maneira acentuada e que a falta de locais para a entrega voluntária dos RSU (ecopontos) contribui significativamente. Indica-se a implantação de sete ecopontos para a captação de RSU nos bairros pesquisados. Sendo: três no bairro Recreio e quatro no bairro Candeias nos locais indicados conforme figura 15.

No bairro Recreio indica-se a implantação de um ecoponto na Conquistinha no mesmo local onde hoje existe um bota-fora e outro nas margens do rio Verruga próximo ao parque de Exposições. No bairro Candeias indica-se a transformação dos bota-foras existentes em ecopontos mediante às orientações técnicas já indicadas nesta pesquisa. Faz-se necessária a intensificação das ações de remoção e de fiscalizações por parte do poder público local, a adoção de medidas educacionais ambientais para a população, punição aos infratores e incentivos fiscais para os geradores que reciclarem direta ou indiretamente os resíduos gerados em obras de construção, reforma e demolição.

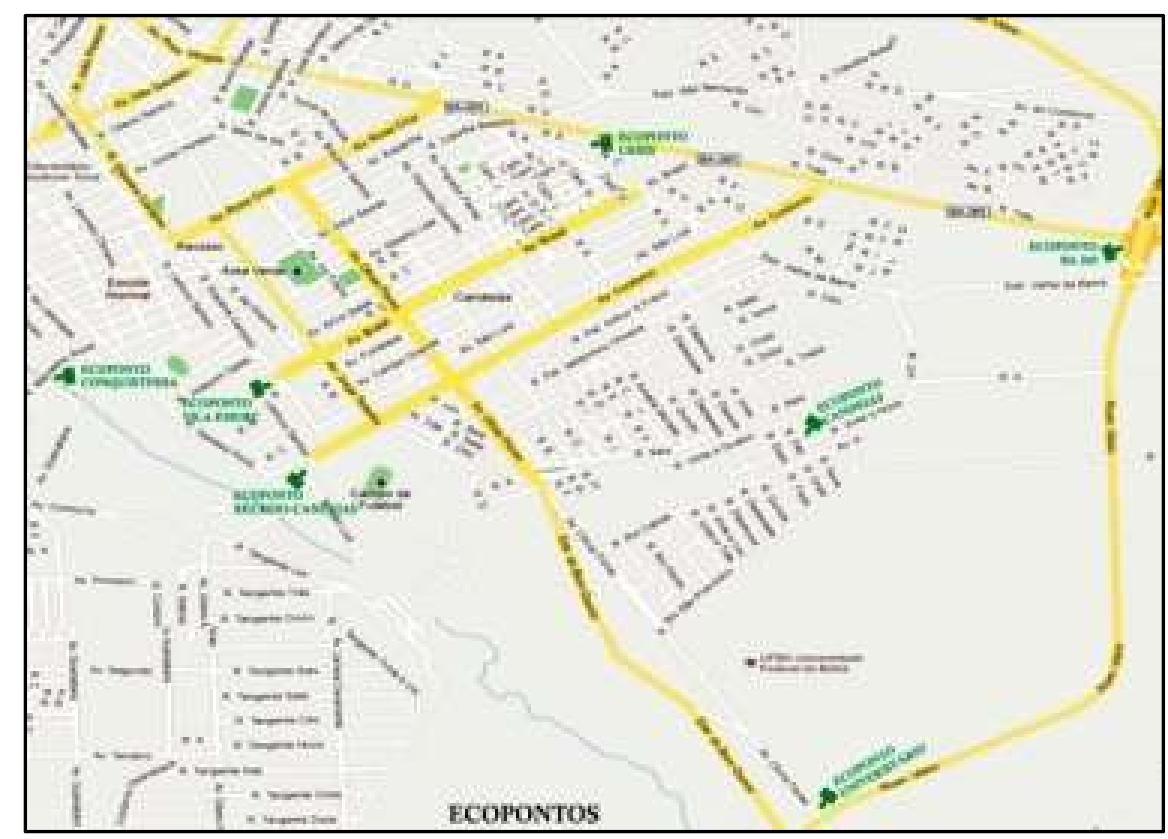

Figura 15: Locais indicados para disponibilização de ecopontos.

Fonte: Sampaio (2011)

Todas as ações deverão ter como alvo principal o esclarecimento e ensinamento da população em relação aos RSU, isto é, redução de geração, deposição, transporte, destinação final adequada. A população deverá ser levada a entender que os impactos ambientais e sociais causados pela deposição irregular desses resíduos em terrenos baldios, margem de córregos, vias públicas, entre outros, bem como o desenvolvimento de projetos, são da responsabilidade de todos. Cada ecoponto atenderá a uma área previamente definida conforme indica a figura 16. 


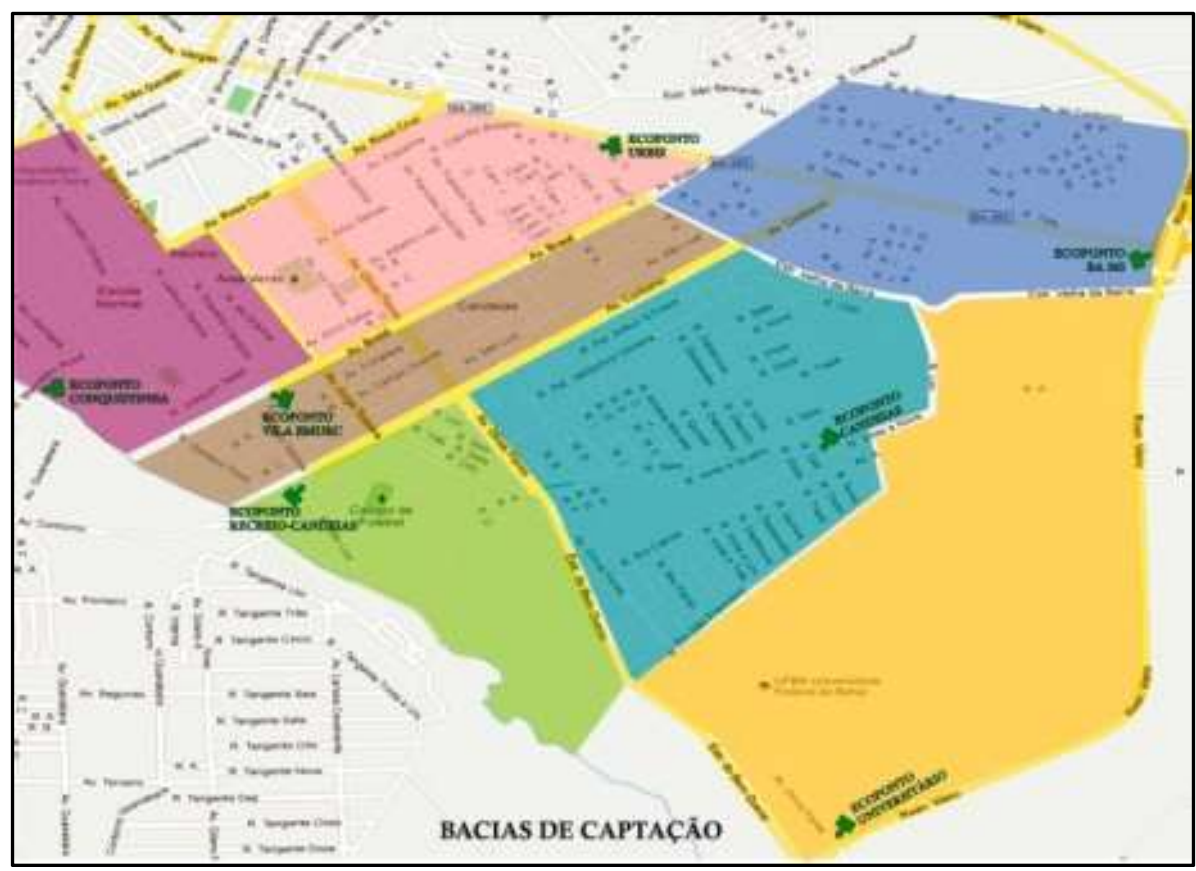

Figura 16: Bacias de captação por ecoponto.

Fonte: Sampaio (2011).

Os objetivos desta definição são: organizar, administrar, disciplinar e facilitar o acesso da população ao ecoponto, levando-se em conta os obstáculos naturais como rio e ladeiras, bem como a acessibilidade urbana. Os locais indicados para os ecopontos obedecem a critérios técnicos já mencionados neste artigo. Em relação ao local para a implantação de uma unidade de reciclagem dos RSU, levando-se em conta os dados desta pesquisa, conforme figura 14 mapeamento dos locais de bota-foras existentes, a figura 13 - distância que os proprietários de empresas "disque entulho" consideram ideal para entregar os RSU, a disponibilidade de espaço fisco, a baixa ocupação territorial e a facilidade de acesso em decorrência da existência do anel viário; a melhor opção é no trecho que fica nas proximidades da estrada dos campinhos.

\section{CONCLUSÕES}

Embora a legislação determine, aja conhecimento científico disponível e a correta gestão dos RSU seja a solução mais favorável para a minimização dos impactos ambientais das deposições irregulares dos RSU sejam economicamente mais vantajosa, é necessário considerar que este resultado é fruto de um longo processo que exigir, da Gestão Pública Municipal, a implantação de uma série de medidas coordenadas e conjugadas que minimizarão os impactos decorrentes da geração dos RSU, em consequência do crescimento populacional municipal, do número de construção de novas residências e das reformas.

Constatou-se que a deposição irregular dos RSU na cidade de Vitória da Conquista tem aumentado de maneira acentuada, acima da média nacional, o município ainda não possui pontos de entrega voluntária de RSU (Ecopontos), necessita implementar as ações de fiscalizações, 
estabelecer políticas educacionais ambientais para a população e cumprir as sanções aos infratores determinadas pela legislação. Foi observado também, que para a gestão pública, a reciclagem dos RSU terá um custo menor do que o custo com a limpeza de locais com deposições irregulares, entretanto, independentemente do uso que for dado aos resíduos, com as seguintes vantagens econômicas, sociais e ambientais quando a correta gestão de RSU é implementada como: decréscimo da poluição gerada por RSU; preservação das reservas minerais não renováveis;

Preservação e redução de áreas de aterros de inertes, minimizando os impactos decorrentes da deposição de RSU; redução do consumo de energia e geração de $\mathrm{CO}^{2}$ na produção e transporte de materiais; redução na poluição visual; benefícios ao meio ambiente e à qualidade de vida da população; redução da utilização dos recursos naturais, que são finitos; geração de emprego e renda; melhoria na qualidade de vida. Pelos resultados até agora alcançados, percebe-se que em relação à gestão de RSU: todas as metodologias têm seus limites e que as pessoas envolvidas, ainda que sejam não especialistas frequentemente sabem mais do que os especialistas e deveriam, portanto, ser consultadas, já que sofrem as consequências diretas das ações antrópicas. Sendo assim, nenhum novo modelo de gestão dos RSU deve ser implementado sem a discursão, a priori, das causas originadoras de tais impactos e sem a participação da sociedade envolvida.

Por outro lado, todo o arcabouço legal emanado do Estado: Resolução 307/2002 do CONAMA; Lei 12305/2010 (PNRS), Lei Federal 10257 (Estatuto da Cidade), bem como as demais resoluções que tratam da geração de resíduos em porto, aeroportos, rodoviárias, hospitais e postos de saúde, trabalham com uma metodologia que analisa a questão dos resíduos após a sua geração, agindo assim, após o fato consumado e, desta maneira, adota um posicionamento, aparentemente, tácito em relação ao sistema de produção, consumo e econômico em vigor.

Observa-se, desta maneira que se faz necessária à reestruturação dos setores públicos e privados responsáveis pela legislação, geração e gerenciamento dos RSU, onde deverá, portanto, refletir as mudanças de paradigma, ditadas pelas necessidades ambientais e humanas atuais, formando um novo modelo econômico onde a sobrevivência no planeta e do planeta estejam no ponto mais alto da cadeia de valor. Entende-se então, que a transformação dos lixões em ecopontos na cidade de Vitória da Conquista, poderá reduzir conflitos entre o modelo econômico adotado pelo Brasil e o meio ambiente, bem como reduzir os custos com a gestão dos RSU e diminuir os impactos sociais.

\section{REFERÊNCIAS}

BRASIL. Conselho Nacional do Meio Ambiente. Resolução CONAMA no 307/02. Estabelece diretrizes, critérios e procedimentos para a gestão dos resíduos da construção civil. Brasília: DOU, 17 de jul 2002.

BRASIL. Lei 12.305, 2 de agosto de 2011. Dispõe sobre a Política Nacional de Resíduos Sólidos (PNRS). Brasília: DOU, 2 ago 2011 
HAWKEN, P.; LOVINS, A.; LOVINS, L. L.. Capitalismo natural: criando a próxima revolução industrial. 4 ed. São Paulo: Cultrix, 2004

JOHN, V. M.. Aproveitamento de resíduos sólidos como materiais de construção, In Carneiro, A. P.; BRUM, I. A. S.; Cassa, J. C. S. (Org.), Reciclagem de entulho para a produção de materiais de construção. Salvador: EDUFBA, 2001

KOVEL, J.. The enemy of nature: the end of Capitalismo or the end of the world? Londres: Zed Books, 2002

LIMA, R. R. R.; LIMA, R. S.. Guia para elaboração de projeto de gerenciamento de resíduos da construção civil. Curitiba: CREA-PR, 2009.

PINTO, T. P.. Reciclagem de resíduos da construção urbana no Brasil. Situação atual, In: WORKSHOP: RECICLAGEM E REUTILIZAÇÃO DE RESÍDUOS COMO MATERIAIS DE CONSTRUÇÃO CIVIL. Anais. São Paulo: EPUSPIANTAC, 1999.

PINTO, T. P.. Resultados da gestão diferenciada. Téchne. n.31, p.31-34, 1999.

PINTO, T.. De volta à questão do desperdício. Construção. São Paulo, v.19, n.271, p.34-35, 1999.

PINTO, T. P.. Recycling in construction sites: environmental responsibility and cost reduction, In: CIB SYMPOSIUM IN CONSTRUCTION AND ENVIRONMENT: THEORY INTO PRACTICE. Anais. São Paulo, Proceedings, 2005

RODRIGUES, E. A. A.. Dinâmica do crescimento urbano na cidade de Vitória da Service life of the building. Application of the performance concept in building. v.2, p.6-11, 2010.

SOUZA, B. J.. Vitória da Conquista enquanto centro oposicionista: revisões e novas leituras, In: ENCONTRO ESTADUAL DE HISTÓRIA, 3. 2008. Anais. Mossoró, 2008.

WILLIAMS, J.. Pós-estruturalismo. Petrópolis: Vozes, 2012. 